\title{
Development of activate-at-home-type edible antimicrobial films: An example pH-triggering mechanism formed for smoked salmon slices using lysozyme in whey protein films
}

\author{
Derya Boyac1, Figen Korel, Ahmet Yemenicioğlu* \\ Department of Food Engineering, Faculty of Engineering, Izmir Institute of Technology, 35430, Gülbahçe Köyü, Urla, Izmir, Turkey
}

\section{A R T I C L E I N F O}

\section{Article history:}

Received 6 October 2015

Received in revised form

20 February 2016

Accepted 23 March 2016

Available online 28 March 2016

\section{Keywords:}

Lysozyme

Whey protein

Edible film

Smoked salmon

Antimicrobial packaging

\begin{abstract}
A B S T R A C T
The aim of the present study was to develop the first generation of a novel natural antimicrobial packaging system which could be activated by consumers at home. For this purpose, antimicrobial films having a pH-triggering mechanism which could be activated by acidification were developed by exploiting isoelectric properties and $\mathrm{pH}$ induced charge-charge interactions between whey proteins (WP) and lysozyme (LYS). The release tests of films in buffers and on coated smoked salmon slices at $4{ }^{\circ} \mathrm{C}$ showed the immobilization of positively charged LYS by the negatively charged WP films at pHs $\geq 5.5$. The LYS release initiated when pH was reduced below 5.5 where WP started to gain positive charges. The amount of LYS released and LYS release rate increased as $\mathrm{pH}$ reduced gradually from 5.5 to 3.0. The preparation of composite films of WP with beeswax (BW) and oleic acid (OLE) increased the total released LYS from films. WP, WP-OLE and WP-BW films showed antimicrobial activity against Listeria innocua in laboratory media. The smoked salmon slices coated by activated LYS containing WP-OLE films showed significantly lower (almost 0.6 decimal) L. innocua counts than controls after 1 week at $4{ }^{\circ} \mathrm{C}$. This study clearly showed that the antimicrobial films could be activated by consumers to improve safety of opened packed food stored in home type refrigerators.
\end{abstract}

() 2016 Elsevier Ltd. All rights reserved.

\section{Introduction}

The rising threat of foodborne outbreaks related to raw and minimally processed products has caused a great interest in functional antimicrobial packaging materials (Cagri, Ustunol, \& Ryser, 2001; Lu, Zhu, Li, \& Chen, 2015; Lynch, Tauxe, \& Hedberg, 2009). Antimicrobial packaging is a promising area since it might inhibit or suppress the growth of pathogenic or spoilage microorganism on food surface by using minimum amounts of antimicrobials (Appendini \& Hotchkiss, 2002; Gennadios, Hanna, \& Kurth, 1997; Han, 2000; Ouattara, Simard, Piette, Bégin, \& Holley, 2000; Quintavalla \& Vicini, 2002). The incorporation of chemical compounds into plastic films is a simple and effective method to develop antimicrobial packaging. However, the growing health concerns of the consumers against chemicals, and environmental problems originating from plastics cause a great interest in using natural antimicrobial compounds and biopolymers in antimicrobial

\footnotetext{
* Corresponding author.

E-mail address: ahmetyemenicioglu@iyte.edu.tr (A. Yemenicioğlu).
}

packaging (Cha \& Chinnan, 2004; Han, 2003; Pérez-Pérez, Regalado-González, Rodríguez-Rodríguez, Barbosa-Rodríguez, \& Villaseñor-Ortega, 2006; Suppakul, Miltz, Sonneveld, \& Bigger, 2003).

Different natural antimicrobials including antimicrobial enzymes, bacteriocins, essential oils and phenolic compounds can be employed in active packaging (Cha \& Chinnan, 2004; Cooksey, 2005; Joerger, 2007; Mastromatteo, Mastromatteo, Conte, \& Del Nobile, 2010). Lysozyme (LYS) obtained from hen egg white is one of the most potential candidates for antimicrobial packaging since it has a Generally Recognized as Safe (GRAS) status. Also, it shows good stability and activity in different films and food systems under refrigerated storage temperatures (Mecitoğlu et al., 2006; Unalan, Korel, \& Yemenicioğlu, 2011). LYS has been tested extensively in different edible materials including zein, gelatin, soy protein, carrageenan, whey protein, chitosan, alginate and pullulan (Cha, Choi, Chinnan, \& Park, 2002; Park, Daeschel, \& Zhao, 2004; Bower, Avena-Bustillos, Olsen, McHugh, \& Bechtel, 2006; Mecitoğlu et al., 2006; Joerger, 2007; Mendes de Souza, Fernández, López-Carballo, Gavara, \& Hernández-Muñoz, 2010).

The LYS shows antimicrobial activity mainly on Gram-positive 
bacteria by splitting the bonds between $\mathrm{N}$-acetylmuramic acid and $\mathrm{N}$-acetylglucosamine of the peptidoglycan in their cell walls (Appendini \& Hotchkiss, 1997; Shah, 2000). Thus, the application of LYS in active packaging targets mainly the inhibition of critical Gram-positive pathogenic bacteria such as Listeria monocytogenes (Duan, Park, Daeschel, \& Zhao, 2007). The prevention of food contamination by L. monocytogenes, and application of hurdles to prevent listerial growth in risky food are critically important since this bacterium may cause deadly infections (Álvarez-Ordóñez, Leong, Hickey, Beaufort, \& Jordan, 2015). It is strongly suggested that individuals highly susceptible to Listeria, such as pregnant women, old people and the immunosuppressed people should be particularly careful during the consumption of risky food (VazquezBoland et al., 2001). The smoked salmon is a typical L. monocytogenes risk food (Dalgaard \& Jørgensen, 1998; Di Ciccio et al., 2012; Vermeulen, Devlieghere, De Loy-Hendrickx, \& Uyttendaele, 2011). However, the struggle against listeriosis in smoked salmon is really challenging since this bacteria could be isolated from different zones of smoked-fish processing plants, and it can grow even at the refrigeration temperatures with or without the presence of oxygen (Dass, Abu-Ghannam, Antony-Babu, \& Cummins, 2010). Thus, vacuum packaging (VP) is not considered as an effective inhibitory hurdle against L. monocytogenes (Duffes, 1999; Gram, 2001). On the other hand, recent studies have shown that it is possible to control L. monocytogenes growth in cold stored smoked salmon slices by MAP containing elevated levels of $\mathrm{CO}_{2}\left(70 \% \mathrm{CO}_{2}\right)$ $30 \% \mathrm{~N}_{2}$ ) (Nilsson, Huss, \& Gram, 1997). However, the protective effect of MAP is lost after opening of the package at home, and the remaining food kept for later consumption becomes quite risky for the development of L. monocytogenes (Buchanan \& Klawitter, 1990; Davies, 1997; Tsigarida, Skandamis, \& Nychas, 2000).

The antimicrobial packaging could be used as a highly effective hurdle to prevent the growth of $L$. monocytogenes not only in smoked salmon but also in other risky foods. For example, Min, Rumsey, and Krochta (2008) successfully employed LYS incorporated whey protein (WP) films to control L. monocytogenes growth on cold stored smoked salmon. In that study, Min et al. (2008) adjusted the $\mathrm{pH}$ of WP film solution during film making to eliminate charge-charge interactions between LYS and WP films, and to ensure the initiation of free enzyme's release from films following food application. On the other hand, Unalan, Arcan, Korel, and Yemenicioğlu (2013) employed LYS containing zein composite films having controlled release properties to prevent the growth of L. monocytogenes in fresh cheese.

The aim of the present work is to develop the first generation of an antimicrobial edible film which can be activated by the consumers. Such a packaging concept which could be named as activate-at-home-type packaging (ActiHome packaging) is novel, and it could be applied by the consumer as a hurdle step for the preservation of VP or MAP food after opening of the packaging and ending of the preservation effect of packaging atmosphere. The ActiHome packaging could reduce poisoning from opened VP or MAP food left for later consumption. It is proposed that the precast ActiHome packaging films containing immobilized antimicrobials might be placed onto top and/or bottom surface and between layers of food or they could be applied as a coating on food surface by the producers. It is desirable that the immobilized antimicrobials at the film surface or within the film provide some antimicrobial effect at the food surface during transportation, storage and marketing. However, it is more important for an ActiHome type packaging to maintain a significant portion of the incorporated antimicrobial during transportation, storage and marketing within the film, but to start to release this antimicrobial after activation of film by the consumer at home. The WP films could be successfully employed as ActiHome type films due to their suitable pI between 4.4 and 5.4
(Etzel, 2004) and their importance as an agro-industrial waste. The use of LYS in WP film system has a good potential since pI of WPs enables binding of this antimicrobial enzyme (positively charged in food systems due to its high pI at 11.4) by the negatively charged WP film matrix when it was employed for packaging of risky food at $\mathrm{pH}$ close to neutrality. The WP-LYS film system forms a perfect $\mathrm{pH}-$ triggering mechanism since it starts to release positively charged LYS by acidification that causes drop of $\mathrm{pH}$ below 5.0. Thus, in the present study, antimicrobial films having a pH-triggering mechanism which could be activated by acidification of consumer at home were developed by exploiting isoelectric properties and $\mathrm{pH}$ induced charge-charge interactions between whey protein (WP) and LYS. The release properties of developed WP films were also modified and improved by the preparation of composites of WP with oleic acid (OLE) and beeswax (BW), respectively. The designed films were tested for their release properties and antimicrobial effects in buffer systems and in a real packaging application conducted with smoked salmon. The present work is the first study planning the participation of consumer in active packaging and reducing incidence of deadly infections by critical pathogens in opened VP and MAP food stored at home for later consumption.

\section{Materials and methods}

\subsection{Materials}

Commercial LYS, Micrococcus lysodeicticus, oleic acid (90\%) and beeswax were obtained from Sigma Chem. Co. (St. Louis, MO, USA). Whey protein isolate $\left(\mathrm{BiPRO}^{\circledR}, 97.8 \%\right.$ protein) was kindly donated by Davisco Foods International, Inc. (MN, USA). Glycerol was obtained from Merck (Darmstadt, Germany). Bacterial strain of Listeria innocua (NRRL B-33314) used in antimicrobial zone tests was provided by United States Department of Agriculture, Microbial Genomics and Bioprocessing Research Unit, Peoria, Illinois. Coldsmoked salmon used in food release tests was obtained from a supermarket in Izmir (Turkey).

\subsection{Film making}

WP films were prepared by the slight modification of the method presented in McHugh and Krochta (1994). Briefly, 10\% (w/ $\mathrm{w}$ ) of WP solution was prepared in distilled water, using magnetic stirrer. Glycerol (at $60 \%$ of WP) was added as plasticizer, and the solution was stirred for $5 \mathrm{~min}$. The film making solution was then incubated in a water bath at $90{ }^{\circ} \mathrm{C}$ for 30 min for protein denaturation, and cooled in ice water bath for $5 \mathrm{~min}$. After that, LYS ( $7.87 \mathrm{mg} / \mathrm{g}$ film solution) was added into medium, and using a homogenizer-disperser (Heidolph, Germany, rotor $\Phi=6.6 \mathrm{~mm}$ tip) the mixture was homogenized at $10,000 \mathrm{rpm}$ for $4 \mathrm{~min}$. The five gram portions of film forming solution was then cast onto plastic Petri dishes (8.5 cm inner diameter), and dried for $24 \mathrm{~h}$ in a controlled test cabinet at $50 \%$ relative humidity and at $25{ }^{\circ} \mathrm{C}$. This procedure was used to obtain standard WP films. The same procedure was also followed to obtain composite films of WP with oleic acid (WP-OLE). The oleic acid (at 9\% of WP) was added after 5 min cooling of the heated film making solution. The LYS was added finally after weighting of film solution. The homogenization, casting and drying steps of WP-OLE films were applied as described above for the standard WP film. However, the sequence of the steps of the method was slightly modified to obtain composites of WP with beeswax (WP-BW). The beeswax (at 30\% of WP) was added in hot film making solutions immediately after heating at $90{ }^{\circ} \mathrm{C}$ for $30 \mathrm{~min}$. The LYS was added finally after weighting of film solution. The homogenization at $10,000 \mathrm{rpm}$ for $4 \mathrm{~min}$ was applied to hot film making solution to enable melting and dispersion of the 
beeswax. The cooling, casting and drying steps for WP-BW films were applied as described above for the standard WP film.

\subsection{LYS activity}

LYS activity was measured spectrophotometrically at $660 \mathrm{~nm}$ by using Shimadzu (Model 2450, Japan) spectrophotometer equipped with a constant temperature cell holder set to $30^{\circ} \mathrm{C}$. Reaction mixture was prepared by mixing $0.1 \mathrm{~mL}$ enzyme containing solution (incubated at $30{ }^{\circ} \mathrm{C}$ for $1 \mathrm{~min}$ ), and $2.4 \mathrm{~mL} \mathrm{M}$. lysodeicticus suspension (at $30^{\circ} \mathrm{C}$ ) prepared in pH $7.0 \mathrm{Na}$-phosphate buffer. After mixing, the decrease in absorbance was monitored for $2 \mathrm{~min}$, and enzyme activity was calculated from the slope of the initial portion of absorbance vs. time curve. Average of three measurements was used in calculations, and enzyme activity was expressed as Units per $\mathrm{cm}^{2}$ of films. One Unit was defined as 0.001 changes in absorbance within $1 \mathrm{~min}$.

\subsection{Release profiles of films placed in different buffer systems}

The LYS release tests were conducted by incubation of WP, WPOLE and WP-BW films at $4{ }^{\circ} \mathrm{C}$ in different buffers between $\mathrm{pH} 3.0$ and 6.0. The buffers at $\mathrm{pH} 4.5,5.0,5.5$ and 6.0 were obtained by using $0.05 \mathrm{M}$ Na-phosphate while, the buffers at $\mathrm{pH} 3.0$ and 4.0 were obtained by $0.05 \mathrm{M}$ Na-acetate-acetic acid buffer. Briefly, films (1/4 of each film, area: $14.2 \mathrm{~cm}^{2}$ ) were placed into glass Petri dishes containing $50 \mathrm{~mL}$ of buffer solution. The dishes were kept at $4{ }^{\circ} \mathrm{C}$ in an incubator and shaken with an orbital shaker working at $80 \mathrm{rpm}$. The release tests of each film were conducted until equilibrium was reached for the release of LYS or an insignificant increase was observed in LYS release. The LYS activity was monitored by taking $0.3 \mathrm{~mL}(3 \times 0.1 \mathrm{~mL})$ aliquots from the release test solution at different time intervals. The enzyme activities in collected aliquots were determined spectrophotometrically as presented in Section 2.3. All calculations were corrected by considering the activity removed by collected aliquots during sampling. The total LYS activity released from each film corresponded to maximum units released per $\mathrm{cm}^{2}$ of the films $\left(\mathrm{U} / \mathrm{cm}^{2}\right)$ at the equilibrium. All activity measurements were conducted for three times. The release curves were formed by plotting the calculated released activities $\left(\mathrm{U} / \mathrm{cm}^{2}\right)$ vs. time (days). The initial release rates of LYS were determined from the slope of the initial linear portion of release curve. The release rates were expressed as $\mathrm{U} / \mathrm{cm}^{2} / \mathrm{h}$.

The protein release from different films was determined by designing separate release tests at the same conditions described for LYS above. However, the sampling $(3 \times 0.1 \mathrm{~mL})$ was done only at the end of release test at $72 \mathrm{~h}$. The protein contents of the samples were determined with the Bradford method by mixing $0.1 \mathrm{~mL}$ portions of samples with $1 \mathrm{~mL}$ of Bradford reagent. After 60 min of incubation, the absorbance of samples was measured at $595 \mathrm{~nm}$. Bovine serum albumin was used as standard and protein solubilized from films were expressed as $\mathrm{mg} / \mathrm{g}$ film dry weight.

\subsection{Release profiles of films placed on smoked salmon slices}

For these release tests, $13 \mathrm{~mm}$ diameter discs of WP, WP-OLE and WP-BW films were placed on one surface of $13 \mathrm{~mm}$ diameter discs obtained from smoked salmon slices (average thickness: $4.02 \pm 0.4 \mathrm{~mm}$; average weight: $0.62 \pm 0.05 \mathrm{~g}$ ). The film and salmon discs were prepared at aseptic conditions, using a sterile cork-borer. The coated salmon discs were first wrapped with a stretch film and then with an aluminium foil to increase edible film-food contact. The packed coated salmon discs were then stored at $4{ }^{\circ} \mathrm{C}$ for $24 \mathrm{~h}$. At the end of $24 \mathrm{~h}$ cold storage, the packs were opened, and $0.2 \mathrm{~mL} 5 \%$ $(\mathrm{w} / \mathrm{v})$ citric acid solution prepared in clarified lemon juice was pipetted onto surfaces of film discs to trigger release of LYS. The samples were then packed again with the stretch film and aluminium foil, and further cold stored for $96 \mathrm{~h}$. The LYS activity released from films to salmons was monitored during cold storage. For determination of the activity salmon discs were homogenized with $10 \mathrm{~mL}$ of deionized water for $2 \mathrm{~min}$, using a homogenizer (IKA, DI18 Basic, Germany). The homogenates were centrifuged at $11,000 \mathrm{rpm}$ for $20 \mathrm{~min}$, and LYS activity was determined in the clear supernatants for three times $(3 \times 0.1 \mathrm{~mL})$ as described in Section 2.3.

\subsection{Antimicrobial activity of films in laboratory media}

The antimicrobial activities of WP, WP-OLE and WP-BW films were determined by the classical zone- inhibition assay, using $L$. innocua (NRRL B-33314) as test microorganism. The inoculums were prepared in pepton water $(0.1 \%)$, using a $24 \mathrm{~h}$ culture of $L$. innocua growth on nutrient agar incubated at $37^{\circ} \mathrm{C}$. The cell concentration was set to $1.0 \mathrm{McFarland}$ unit $\left(3 \times 10^{8} \mathrm{CFU} / \mathrm{mL}\right)$. Fifteen discs were cut from each film by a cork-borer under aseptic conditions and three discs were placed onto surfaces of each inoculated agar. Petri dishes were then incubated at $37^{\circ} \mathrm{C}$ for $48 \mathrm{~h}$, and the area of clear zones formed around the discs was calculated by using a digital micrometer.

\subsection{Antimicrobial activity of films on coated smoked salmon slices}

The $L$. innocua was activated by transferring one loop of frozen culture $\left(-80^{\circ} \mathrm{C}\right)$ to $9 \mathrm{~mL}$ brain heart infusion broth (BHIB) (Merck, Darmstad, Germany) and incubating at $37{ }^{\circ} \mathrm{C}$ for $24 \mathrm{~h}$. One-mL aliquot from the active culture was transferred to the BHIB, and incubated at $4{ }^{\circ} \mathrm{C}$ for an additional $24 \mathrm{~h}$ for adaptation of its growth at cold storage temperature. After dilution with $0.1 \%$ pepton water (Merck, Darmstad, Germany) an inoculum of $1 \times 10^{7} \mathrm{CFU} / \mathrm{mL}$ was obtained for the inoculation of food sample. The surfaces of the smoked salmon slices (Size: $4 \times 4 \mathrm{~cm}$, Weight: $10 \mathrm{~g}$ ) were inoculated with $0.125 \mathrm{~mL}$ of inoculum, and the inoculum was spread with a sterile plastic spreader. The inoculated slices were kept in a sterile condition in safety cabinet for $10 \mathrm{~min}$ for absorption of the inoculum, and then antimicrobial films at the same size were placed carefully on their surfaces. The films were then acidified for triggering the release of LYS by pipetting $0.5 \mathrm{~mL} 5 \%(\mathrm{w} / \mathrm{v})$ citric acid solution prepared in clarified lemon juice onto their surface and spreading this solution with a sterile plastic spreader. Controls were prepared similarly without acidification. Each coated smoked salmon slice was then wrapped with a plastic film and then with an aluminium foil. The five different groups used in active packaging were as follows: (1) Uncoated samples, (2) Samples coated with WP-OLE films, (3) Samples coated with WP-OLE films containing LYS $\left(0.7 \mathrm{mg} / \mathrm{cm}^{2}\right)$, (4) Samples coated with WP-OLE films, and acidified, (5) Samples coated with WP-OLE films containing LYS $\left(0.7 \mathrm{mg} / \mathrm{cm}^{2}\right)$ and acidified. The samples were stored at $4{ }^{\circ} \mathrm{C}$, and enumerated for their $L$. innocua counts periodically, at $0^{\text {th }}, 1^{\text {st }}, 3^{\text {rd }}$, $5^{\text {th }}$ and $7^{\text {th }}$ days of cold-storage. During bacterial counts each salmon slice (10 g) was placed into a stomacher bag containing $90 \mathrm{~mL}$ sterile $0.1 \%$ peptone water, and homogenized for $60 \mathrm{~s}$ by using a stomacher (BagMixer ${ }^{\circledR} 400$, Interscience, France). The serial decimal dilutions were prepared from this homogenate, and appropriate dilutions $(0.1 \mathrm{~mL})$ were spread plated onto Oxford Listeria Selective Agar (Merck, Darmstad, Germany) containing Oxford Listeria Selective Supplement (Merck, Darmstad, Germany). The plates were incubated at $37^{\circ} \mathrm{C}$ for $48 \mathrm{~h}$, and small black colonies with halos on the plates were enumerated. The counts were performed in triplicate plates. The three separate samples for each of the five different groups were analysed at each sampling day. 


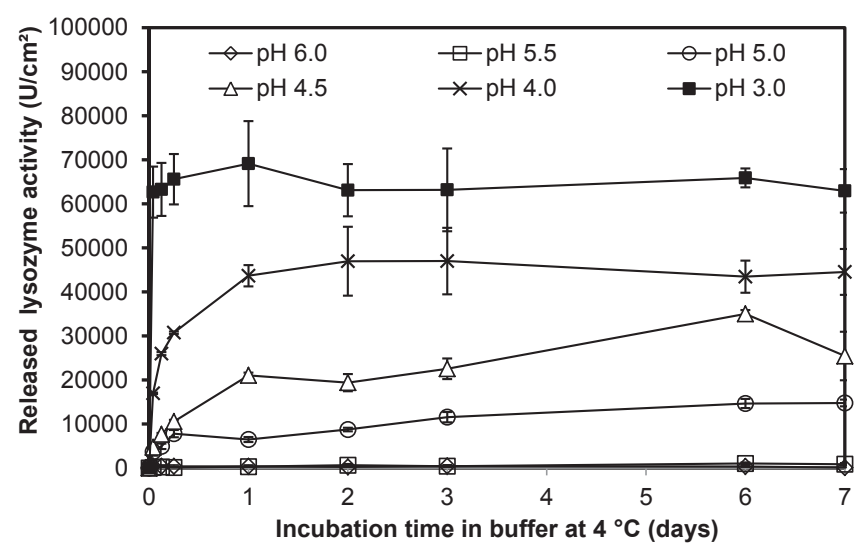

Fig. 1. Release profiles of LYS from WP films incubated at $4{ }^{\circ} \mathrm{C}$ in buffers with different $\mathrm{pH}$ values.

Microbiological counts were converted to $\log \mathrm{CFU} \mathrm{g}{ }^{-1}$, and the means and standard deviations were calculated.

\subsection{Mechanical properties of films}

Tensile strength at break, elongation at break and elastic modulus were determined, using a Texture Analyser TA-XT2 (Stable Microsystems, Godalming, UK) according to ASTM Standard Method D- 882-02 (ASTM, 2002). Films were cut into $8 \mathrm{~mm}$ wide and $80 \mathrm{~mm}$ length strips. The initial grip distance was $50 \mathrm{~mm}$, and the crosshead speed was $50 \mathrm{~mm} / \mathrm{min}$. At least seven replicates of each film were tested.

\subsection{Moisture contents of films}

The moisture contents of films were determined by the vacuum oven drying method applied at $70{ }^{\circ} \mathrm{C}$ and $16.9 \mathrm{kPa}$ until reaching a stable dry film weight (minimum $24 \mathrm{~h}$ ). The moisture contents of WP, WP-OLE and WP-BW films were $40.8 \pm 1.3 \%, 38.4 \pm 1.6 \%$, and $33.6 \pm 1.6 \%$, respectively.

\subsection{Statistical analysis}

Statistical analysis was performed by using MINITAB ${ }^{\circledR}$ release 17 (Minitab Inc., State College, Pa., U.S.A.). LYS activities, antimicrobial inhibition zones, microbial counts and mechanical properties were analysed by using one-way analysis of variance (ANOVA). Significance threshold was $\mathrm{p}<0.05$.

\section{Results and discussion}

\section{1. pH controlled LYS release profiles of different films in buffer systems}

\subsubsection{Release profiles of WP films}

The LYS release profiles of WP films in buffers with different $\mathrm{pHs}$ at $4{ }^{\circ} \mathrm{C}$ were presented in Fig. 1. The pI of major WP fractions changed between 4.4 and 5.4 (Etzel, 2004), while pI of LYS is at 11.4 (Product information sheet, Sigma-Aldrich, USA). Thus, effective binding of positively charged LYS by the negatively charged WP occurred, and the films did not release any considerable enzyme activity at pH 5.5 and 6.0. The films incubated at pH 5.0, which is close to the pI of protein fractions forming WP, released LYS slowly. However, the total amount of enzyme activity released from these films at the equilibrium reached within 7 days incubation was low and corresponded only $22 \%$ of LYS activity incorporated into films $\left(14,776 \mathrm{U} / \mathrm{cm}^{2}\right)$ (Table 1$)$. In contrast, the films incubated at $\mathrm{pH} 4.5$, 4.0 and 3.0 released almost 2, 3 and 5 fold higher total LYS activity at their equilibrium than films incubated at pH 5.0, respectively. It is important to report that the activity of LYS released from WP films at $\mathrm{pH} 3.0$ was almost equal to the LYS activity incorporated into films (activity released corresponded to $102 \%$ of activity incorporated). These data clearly showed the roles of attractive and repulsive charge-charge interactions formed among ionisable groups of LYS and WP in binding and release of LYS. It is clear that the $\mathrm{pH}$ drop caused loss of attractive charge-charge interactions between positively charged LYS and WP film matrix which started to gain positive charges while its negative charges disappeared. Moreover, the LYS release rates of films increased as $\mathrm{pH}$ of the release medium was reduced. In fact, it is worth to note that the LYS release rate of films incubated at $\mathrm{pH} 3.0$ is 4.2 and 7.7 fold higher than those incubated at $\mathrm{pH} 4.5$ and 4.0 , respectively. It appeared

Table 1

Initial LYS release rates and total released LYS activities from WP, WP-OLE and WP-BW films placed in buffer at different pH values.

\begin{tabular}{|c|c|c|c|c|c|c|c|c|}
\hline \multicolumn{3}{|c|}{ Film composition } & \multirow[t]{2}{*}{$\mathrm{pH}$} & \multirow{2}{*}{\multicolumn{2}{|c|}{$\begin{array}{l}\text { Initial lysozyme release } \\
\text { rate }\left(\mathrm{U} / \mathrm{cm}^{2} / \mathrm{h}\right)\end{array}$}} & \multirow{2}{*}{\multicolumn{3}{|c|}{ Total released lysozyme activity $\left(\mathrm{U} / \mathrm{cm}^{2}\right)$}} \\
\hline \multirow{2}{*}{$\begin{array}{l}\mathrm{LYS}\left(\mathrm{mg} / \mathrm{cm}^{2}\right) \\
0.7\end{array}$} & \multirow{2}{*}{$\frac{\operatorname{OLE}(\%)^{\mathrm{h}}}{-}$} & \multirow{2}{*}{$\frac{\mathrm{BW}(\%)}{-}$} & & & & & & \\
\hline & & & 3.0 & 62,676 & $(0-1)^{\mathrm{i}}$ & $69,138 \pm 9663^{a}$ & $(102 \%)^{k}$ & $(1)^{\mathrm{j}}$ \\
\hline 0.7 & - & - & 4.0 & 8066.8 & $(0-3)$ & $47,019 \pm 7552^{c}$ & $(70 \%)$ & (3) \\
\hline 0.7 & - & - & 4.5 & 1496.5 & $(0-3)$ & $35,021 \pm 853^{\mathrm{e}}$ & $(52 \%)$ & (6) \\
\hline 0.7 & - & - & 5.0 & 1513 & $(0-3)$ & $14,776 \pm 770^{g}$ & $(22 \%)$ & (7) \\
\hline 0.7 & - & - & 5.5 & No cons & elease & & & \\
\hline 0.7 & - & - & 6.0 & No cons & elease & & & \\
\hline 0.7 & 9 & - & 4.0 & 9875.3 & $(0-3)$ & $51,391 \pm 1983^{b c}$ & $(76 \%)$ & (3) \\
\hline 0.7 & 9 & - & 4.5 & 3221.9 & $(0-3)$ & $74,184 \pm 6730^{\mathrm{a}}$ & $(110 \%)$ & (7) \\
\hline 0.7 & 9 & - & 5.0 & 1918 & $(0-3)$ & $23,817 \pm 647^{\mathrm{f}}$ & $(35 \%)$ & (7) \\
\hline 0.7 & 9 & - & 5.5 & No cons & elease & & & \\
\hline 0.7 & - & 30 & 4.0 & 11,288 & $(0-3)$ & $56,811 \pm 954^{\mathrm{b}}$ & $(84 \%)$ & $(8)$ \\
\hline 0.7 & - & 30 & 4.5 & 3004.5 & $(0-3)$ & $40,709 \pm 3592^{\mathrm{d}}$ & $(60 \%)$ & (7) \\
\hline 0.7 & - & 30 & 5.0 & 1705 & $(0-3)$ & $20,821 \pm 1215^{\mathrm{fg}}$ & $(31 \%)$ & $(8)$ \\
\hline 0.7 & - & 30 & 5.5 & No cons & elease & & & \\
\hline
\end{tabular}

\footnotetext{
${ }^{a-g}$ Different letters in each column show significant differences at $\mathrm{p}<0.05$.

${ }^{\mathrm{h}}$ Concentrations of beeswax and oleic acid as \% of WP (w/w).

${ }^{\mathrm{i}}$ Time periods (h) of data used in best fit. $\mathrm{R}^{2}$ value varies between 0.73 and 1 .

$\mathrm{j}$ Time (days) at which the equilibrium was reached for LYS release.

${ }^{\mathrm{k}}$ Proportion of released LYS activity incorporated in the film.
} 


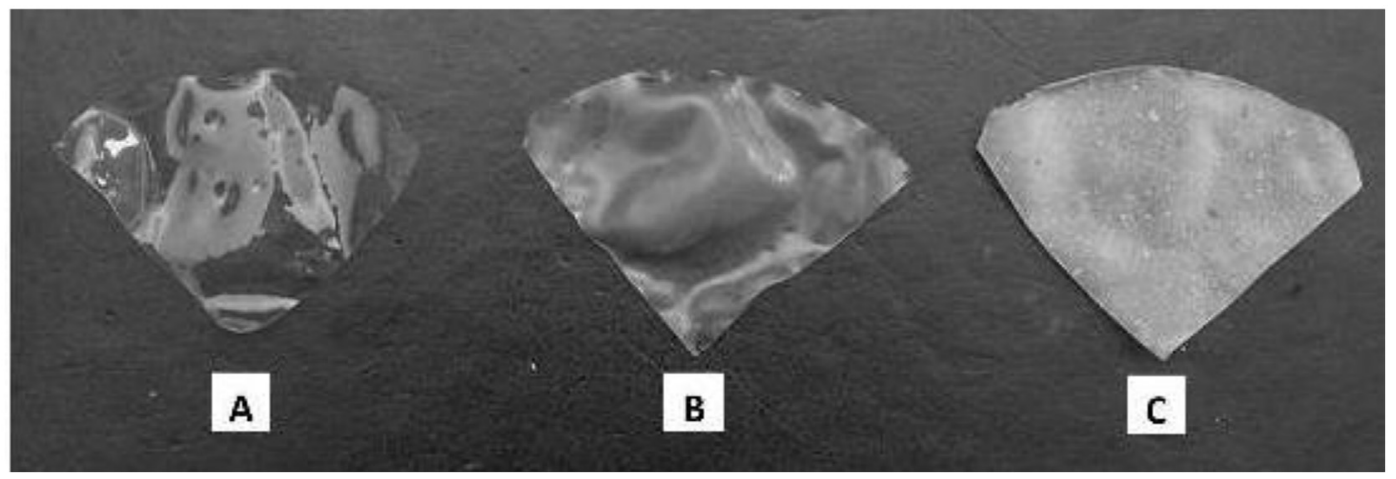

Fig. 2. Photographs of WP (A), WP-OLE (B) and WP-BW (C) films following release tests conducted at pH 5.0 for $72 \mathrm{~h}$ at $4{ }^{\circ} \mathrm{C}$.

that the acceleration of LYS release by $\mathrm{pH}$ drop is due to the increased repulsion between the positively charged enzyme molecules, and WP which net positive charges increased as $\mathrm{pH}$ was reduced below its pI. These results clearly showed the possibility of controlling release rate and total amount of LYS released from WP films by changing the $\mathrm{pH}$ of release medium. This finding forms the basis of designing ActiHome type antimicrobial edible films which can be activated by the consumer simply by acidification of film placed into the package (on food surface, on bottom of food or between food layers) by the producer.

\subsubsection{Release profiles of WP-BW and WP-OLE films}

The incorporation of different fatty acids and waxes into films, and preparation of composite structures is frequently employed to modify morphologies, release profiles, permeability characteristics and mechanical properties of edible films (Arcan \& Yemenicioğlu,
2013; Fabra, Talens, \& Chiralt, 2008). In this work, the composites of WP with OLE and BW were prepared to create chemical and physical modifications in WP film matrix and change its LYS release profiles. The incorporation of OLE into WP films caused the formation of a protein-fatty acid emulsion and this turned transparent WP films to slightly opaque (Fig. 2A and B). On the other hand, the incorporation of BW caused the formation of numerous microscopic wax particles within the films and this tuned transparent WP films to highly opaque (cloudy) (Fig. 2C).

The release profiles of WP films and their composites between $\mathrm{pH} 4.0$ and 5.5 are seen in Fig. 3A-D. Similar to the results obtained for WP films, the charge-charge attractions between positively charged LYS and negatively charged WP film matrix at pH 5.5 prevented the release of enzyme from WP-OLE and WP-BW composite films (Fig. 3A). However, the reduction of $\mathrm{pH}$ to 5.0 initiated release of the LYS from composite films. The release curves
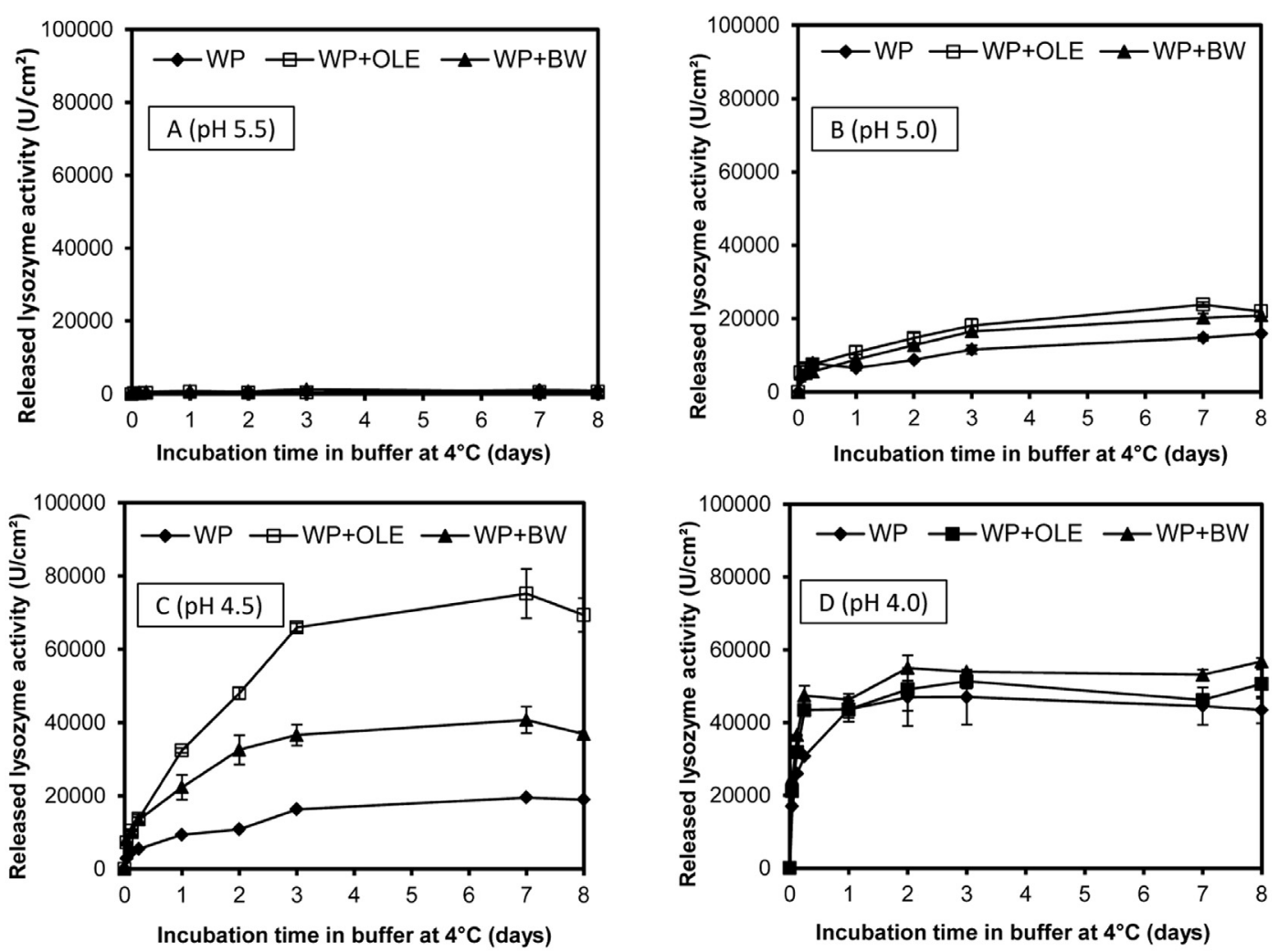

Fig. 3. Release profiles of LYS from WP, WP-OLE and WP-BW films incubated at $4{ }^{\circ} \mathrm{C}$ in buffers with different pH values. 


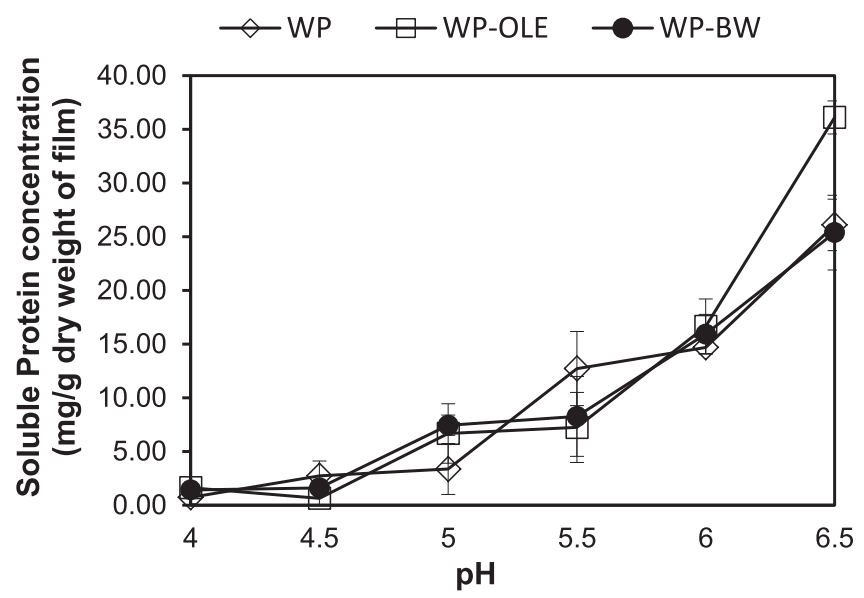

Fig. 4. Protein solubility from films incubated for $72 \mathrm{~h}$ in buffers at different $\mathrm{pH}$ at $4{ }^{\circ} \mathrm{C}$.

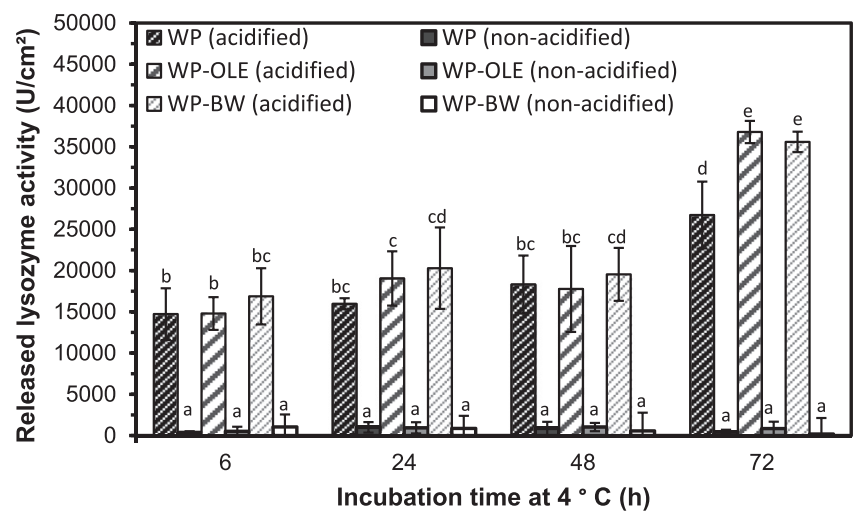

Fig. 5. The increased LYS release from WP, WP-OLE and WP-BW films on surfaces of coated smoked salmon discs following acidification (acidification was conducted with $5 \%(\mathrm{w} / \mathrm{v})$ citric acid solution prepared in lemon juice).

obtained at pH 5.0 and 4.5 (Fig. 3B and C) clearly showed the higher LYS release rates and total amounts of released LYS from composite films at the equilibrium than WP films. On the other hand, similar LYS release rates and total released LYS activities were observed for all films at $\mathrm{pH} 4.0$ (Fig. 3D). This finding suggested the dominance of repulsive charge-charge forces in LYS release from all films at $\mathrm{pH}$ 4.0. It is important to note that the total amount of LYS released from WP-OLE films at $\mathrm{pH} 4.5$ was 1.8 and 2.1 fold higher than those of WP-BW and WP films, respectively. It is interesting to report that the released activity from WP-OLE films at $\mathrm{pH} 4.5$ corresponded to $110 \%$ of calculated incorporated LYS activity in these films. The $10 \%$ higher activity of released LYS activity than that of calculated incorporated LYS activity could be simply due to slight heterogeneities in film thickness or in enzyme distribution within the films (quarter of round cast films were cut and used in release tests). Thus, this result practically means that almost all LYS released from WP-OLE films at $\mathrm{pH}$ 4.5. The results of release tests for WP films showed that these films should be incubated at $\mathrm{pH} 3.0$ to release all their LYS. Thus, it is clear that the use of WP-OLE composites in food application at $\mathrm{pH} 4.5$ instead of WP films could be more beneficial to increase LYS release on food surface.

The protein release profiles of WP, WP-OLE, and WP-BW control (films lacking LYS) films at the end of $72 \mathrm{~h}$ incubation at $4{ }^{\circ} \mathrm{C}$ in different buffers were also presented in Fig. 4. The films showed quite similar protein solubility between $\mathrm{pH} 4.0$ and 6.5. The protein solubility of films was at insignificant levels $(\leq 1 \%$ of film dry weight) at $\mathrm{pH} 4.0,4.5$ and 5.0 (a range that is critical for release of LYS from films). A slight increase was observed in protein solubility above $\mathrm{pH}$ 5.0, but the maximum solubility was still below $3.7 \%$ of dry film weight even at $\mathrm{pH}$ 6.5. The films used in the current study were obtained after effective heat denaturation of whey protein (see Section 2.2) at $90{ }^{\circ} \mathrm{C}$ for $30 \mathrm{~min}$. Thus, they contain very little amount of soluble protein at the $\mathrm{pH}$ range ( $\mathrm{pH} 4.5$ and 5.0) designed for activation of films by $\mathrm{pH}$ triggering. These results showed that the higher LYS release from WP-OLE and WP-BW films than WP films was not due to increased protein erosion from matrices of composite films. The WP that forms the film matrix is directly responsible for charge-charge binding (due to attraction) and release (due to repulsion) of LYS from the films when $\mathrm{pH}$ was changed. Due to their composite structures, the WP-OLE (9\% of WP was changed with OLE) and WP-BW (30\% of WP was changed with BW) films contain lower amounts of WP than the WP films. Thus, the reduced WP content of composite films and declined number of charge-charge interactions between LYS and composite film matrix might be a factor effective on increased LYS release from WPOLE and WP-BW films. This factor should be more effective on release profiles of WP-BW films than those of WP-OLE films, since $30 \%$ of WP was changed with BW in these composite films. On the other hand, in WP-OLE films only 9\% of WP was changed with OLE. Thus, there should be some other factors affecting the higher amounts of LYS release from WP-OLE films than WP-BW films at $\mathrm{pH}$ $=4.5$. It appeared that the emulsion formed between WP and OLE might have caused a shift in the pKa of WP by masking some of the charged groups of this protein. The release of highest amount of LYS from WP-OLE films occurred at $\mathrm{pH}$ 4.5. Thus, it is possible that the effects of emulsion induced changes (like masking) in charges of WP-OLE film matrix were maximized at $\mathrm{pH} 4.5$, and this triggered

Table 2

Antimicrobial activity of WP, WP-OLE and WP-BW films on L. innocua in laboratory media with and without acidification.

\begin{tabular}{|c|c|c|c|c|c|}
\hline \multicolumn{4}{|c|}{ Film composition } & \multicolumn{2}{|c|}{ Average area of clear zones $\left(\mathrm{mm}^{2}\right)$ at $4{ }^{\circ} \mathrm{C}$} \\
\hline LYS $\left(\mathrm{mg} / \mathrm{cm}^{2}\right)$ & OLE $(\%)^{\mathrm{e}}$ & BW (\%) & Acidification $^{f}$ & $24 \mathrm{~h}$ & $48 \mathrm{~h}$ \\
\hline- & - & - & - & No clear zone & No clear zone \\
\hline - & - & - & + & No clear zone & No clear zone \\
\hline 0.7 & - & - & - & $51.7 \pm 8.5^{\mathrm{d}}$ & $63.5 \pm 13.9^{c}$ \\
\hline 0.7 & - & - & + & $101.1 \pm 15.3^{c}$ & $84.6 \pm 22.5^{\mathrm{b}}$ \\
\hline 0.7 & 9 & - & - & $121.5 \pm 14.9^{\mathrm{b}}$ & $93.9 \pm 17.4^{\mathrm{b}}$ \\
\hline 0.7 & 9 & - & + & $141.6 \pm 26.6^{a}$ & $124.3 \pm 32.7^{a}$ \\
\hline 0.7 & - & 30 & - & $54.5 \pm 7.4^{\mathrm{d}}$ & $55.6 \pm 11.04^{\mathrm{c}}$ \\
\hline 0.7 & - & 30 & + & $58.5 \pm 21.2^{\mathrm{d}}$ & $88.11 \pm 55.6^{c}$ \\
\hline
\end{tabular}

a-d Different letters within each incubation time show significant differences at $\mathrm{p}<0.05$.

e Concentrations of beeswax and oleic acid as \% of WP $(w / w)$.

f $5 \%(w / v)$ citric acid solution in lemon juice. 
extensive LYS release from films due to minimized attractive charge-charge interactions between LYS and film matrix.

\section{2. $p H$ controlled LYS release profiles of films in coated cold stored smoked salmon slices}

The designed $\mathrm{pH}$-controlled release system was tested on WP, WP-BW and WP-OLE films coated smoked salmon slices cold stored at $4{ }^{\circ} \mathrm{C}$. The film surfaces of half of the packed samples were acidified to test working of the pH-controlled triggering mechanism designed to initiate LYS release to salmon slices while the other half of the packed samples were cold stored without acidification. Fig. 5 shows the lack of any considerable LYS release from the films in non-acidified salmon controls that average $\mathrm{pH}$ value is almost 6.3. This result confirms the stability of attractive charge-charge interactions between LYS and WP film matrix at the initial $\mathrm{pH}$ of target food. In contrast, the release of LYS from films to food surface initiated in all samples following acidification that dropped $\mathrm{pH}$ of salmon slices from 6.3 to 6.4 to $4.5-4.6$. There are no statistically significant differences among LYS activity of salmon slices packed with acidified WP, WP-OLE and WP-BW films up to $48^{\text {th }}$ hour of cold storage $(p>0.05)$. However, LYS activities released on salmon slices packed with acidified WP-OLE and WP-BW composite films were $37 \%$ and $33 \%$ higher than those released on salmon slices packed with standard WP films $(\mathrm{p}<0.05)$ at the end of $72 \mathrm{~h}$ cold storage, respectively. Different from the results obtained in buffer systems, the difference between total released LYS activities of acidified WP-OLE and WP-BW coated salmon slices were not statistically significant $(p>0.05)$. It should also be reported that LYS activities released on salmon slices from $\mathrm{cm}^{2}$ of WP, WP-OLE and WP-BW films within $72 \mathrm{~h}$ at $+4{ }^{\circ} \mathrm{C}$ were $24 \%, 50 \%$ and $13 \%$ lower than those released from these films in buffer at $\mathrm{pH} 4.5$ at $+4{ }^{\circ} \mathrm{C}$ (at equilibrium), respectively. It is possible that the reduced LYS activity release onto salmon slices was due to more limited swelling of films on salmon surfaces than in the buffers. However, quantitative LYS determination is needed to prove this hypothesis due to some potential changes in LYS activity by active proteases in salmon and by complex formation with salmon constituents. On the other hand, these results clearly showed the working of the designed $\mathrm{pH}$ controlled release system in cold stored smoked salmon. Moreover, the beneficial effect of using composite WP-OLE and WP-BW films in increasing LYS delivery was also clearly demonstrated.

\subsection{Antimicrobial activity of films}

\subsubsection{Antimicrobial activity of films in classical zone-inhibition test}

Antimicrobial tests in this part targeted determining the effects of composite film making on antilisterial activity of films. Table 2 shows the antimicrobial properties of WP films and its composites following $24 \mathrm{~h}$ and $48 \mathrm{~h}$ incubation periods at $37^{\circ} \mathrm{C}$. During antimicrobial tests the control films (acidified or non-acidified) did not form any clear zone areas, but the formation of turbid zones very close to film disc borders (almost $1 \mathrm{~mm}$ ) was observed around control WP films. This result suggested a limited inherent antimicrobial activity of films against $L$. innocua, possibly due to the presence of some residual natural antimicrobial milk components like lactoferrin or antimicrobial peptides in the commercial WP preparation. The limited antilisterial effect of films obtained from the same commercial WP product was also reported by Unalan, Ucar, Arcan, Korel \& Yemenicioğlu, (2011). However, it should also be reported that some extensive bacterial growth was also observed at the bottom of control films (Fig. 6). On the other hand, both acidified and non-acidified WP, WP-OLE and WP-BW films containing LYS caused formation of clear zones on L. innocua. The acidification of films caused significant increases in average area of

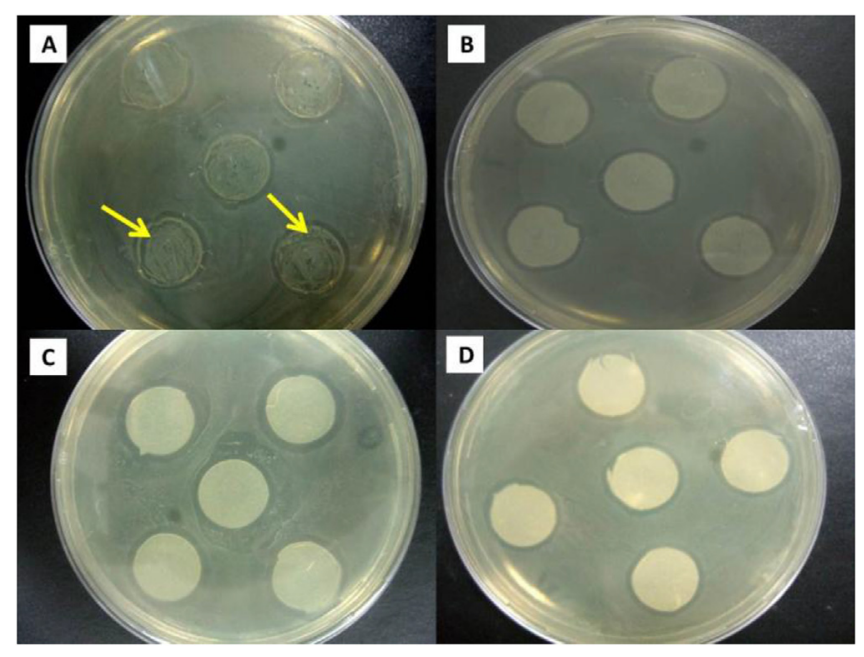

Fig. 6. Inhibitory zones on L. innocua caused by control WP (A), and LYS containing WP (B), WP-OLE (C), WP-BW (D) films (the arrows indicate bacterial growth under control films. No bacterial growth was observed below LYS containing films).

clear zones formed by WP and WP-OLE films containing LYS $(p<0.05)$. In contrast, the acidification of films and the activation of LYS release did not cause any significant increases in the antimicrobial activity of LYS containing WP-BW films. It is also worth to report that the non-acidified LYS containing WP and WP-BW films showed similar antimicrobial activity while acidified LYS containing WP-BW films showed lower antimicrobial activity than acidified LYS containing WP films. These results suggested the change of LYS release profiles of WP-BW films at $37{ }^{\circ} \mathrm{C}$ within $24 \mathrm{~h}$. It appeared that the modifications in the wax component, such as softening and melting at $37{ }^{\circ} \mathrm{C}$ which is essential to apply for obtaining bacterial growth during incubation caused the migration of wax components within the film matrix to film surface, and this formed a hydrophobic barrier for diffusion of LYS to agar. On the other hand, for both acidified and non-acidified films the highest antimicrobial activity was observed for WP-OLE films. This finding compared well with the release test experiments conducted in buffers and showed the release of highest amounts of LYS from WPOLE films.

\subsubsection{Antimicrobial activity of films on cold stored coated smoked salmon slices}

The WP-OLE film, which showed superior performance than the

Table 3

Antimicrobial activity of WP and WP-OLE films on L. innocua inoculated smoked salmon slices cold stored at $4{ }^{\circ} \mathrm{C}$.

\begin{tabular}{|c|c|c|c|c|}
\hline \multicolumn{5}{|c|}{ L. innocua counts during storage at $4{ }^{\circ} \mathrm{C}(\log \mathrm{CFU} / \mathrm{g})$} \\
\hline Day 0 & Day 1 & Day 3 & Day 5 & Day 7 \\
\hline Uncoated & & & & \\
\hline $\begin{array}{l}4.98 \pm 0.08^{\mathrm{a}, \mathrm{A}} \\
W P-O L E \text { (contro }\end{array}$ & $\begin{array}{l}4.82 \pm 0.10^{\mathrm{ab}, \mathrm{B}} \\
\mathrm{ol})\end{array}$ & $4.82 \pm 0.10^{\mathrm{a}, \mathrm{B}}$ & $4.80 \pm 0.11^{\mathrm{a}, \mathrm{B}}$ & $4.83 \pm 0.13^{\mathrm{a}, \mathrm{B}}$ \\
\hline $\begin{array}{l}4.92 \pm 0.10^{\mathrm{a}, \mathrm{A}} \\
W P-O L E+L Y S\end{array}$ & $4.72 \pm 0.10^{\mathrm{bc}, \mathrm{C}}$ & $4.73 \pm 0.08^{\mathrm{b}, \mathrm{C}}$ & $4.78 \pm 0.09^{\mathrm{a}, \mathrm{BC}}$ & $4.84 \pm 0.11^{\mathrm{a}, \mathrm{B}}$ \\
\hline $\begin{array}{l}4.92 \pm 0.08^{\mathrm{a}, \mathrm{A}} \\
\text { WP-OLE (acidifi }\end{array}$ & $\begin{array}{l}4.68 \pm 0.07^{\mathrm{c}, \mathrm{B}} \\
\text { fied) }\end{array}$ & $4.69 \pm 0.15^{\mathrm{b}, \mathrm{B}}$ & $4.74 \pm 0.12^{\mathrm{a}, \mathrm{B}}$ & $4.49 \pm 0.12^{\mathrm{b}, \mathrm{c}}$ \\
\hline $\begin{array}{l}4.97 \pm 0.04^{\mathrm{a}, \mathrm{A}} \\
W P-O L E+L Y S\end{array}$ & $\begin{array}{l}4.84 \pm 0.11^{\mathrm{a}, \mathrm{B}} \\
\text { (acidified) }\end{array}$ & $4.77 \pm 0.13^{\mathrm{ab}, \mathrm{B}}$ & $4.80 \pm 0.12^{\mathrm{a}, \mathrm{B}}$ & $4.57 \pm 0.09^{\mathrm{b}, \mathrm{c}}$ \\
\hline $4.97 \pm 0.07^{\mathrm{a}, \mathrm{A}}$ & $4.49 \pm 0.13^{\mathrm{d}, \mathrm{B}}$ & $4.45 \pm 0.13^{\mathrm{c}, \mathrm{BC}}$ & $4.27 \pm 0.19^{\mathrm{b}, \mathrm{BC}}$ & $4.24 \pm 0.15^{\mathrm{c}, \mathrm{C}}$ \\
\hline
\end{tabular}


Table 4

Mechanical properties of WP, WP-OLE and WP-BW films.

\begin{tabular}{|c|c|c|c|c|c|c|}
\hline \multicolumn{3}{|c|}{ Film composition } & \multicolumn{4}{|l|}{ Mechanical properties } \\
\hline LYS $\left(\mathrm{mg} / \mathrm{cm}^{2}\right)$ & $\mathrm{OLE}(\%)^{\mathrm{c}}$ & $\overline{\mathrm{BW}(\%)}$ & Film thickness $(\mu \mathrm{m})$ & Tensile strength (MPa) & Elongation at break (\%) & Young's modulus (MPa) \\
\hline- & - & - & $69 \pm 0.4$ & $2.9 \pm 0.03^{\mathrm{a}}$ & $14.7 \pm 0.3^{\mathrm{b}}$ & $17 \pm 1.3^{\mathrm{a}}$ \\
\hline 0.7 & - & - & $71 \pm 0.7$ & $2.8 \pm 0.44^{\mathrm{a}}$ & $37.7 \pm 12^{\mathrm{a}}$ & $7.6 \pm 2.1^{\mathrm{b}}$ \\
\hline 0.7 & 9 & - & $76 \pm 1.2$ & $2.8 \pm 0.26^{\mathrm{a}}$ & $30.1 \pm 11.2^{\mathrm{a}}$ & $10.7 \pm 5^{b}$ \\
\hline 0.7 & - & 30 & $103 \pm 5.2$ & $2.1 \pm 0.14^{\mathrm{b}}$ & $14.1 \pm 3.5^{b}$ & $15.6 \pm 3.3^{\mathrm{a}}$ \\
\hline
\end{tabular}

${ }^{\mathrm{a}-\mathrm{b}}$ Different letters in each column show significant difference at $\mathrm{p}<0.05$.

${ }^{c}$ Concentrations of beeswax and oleic acid as \% of WP (w/w).

WP-BW film in release tests and antimicrobial tests was selected for the food application. The acidification conducted with $5 \%(\mathrm{w} / \mathrm{v})$ citric acid solution prepared in clarified lemon juice brought the salmon slice pH from 6.3-6.4 to 4.5-4.6, a critical pH level which caused maximum LYS release from WP-OLE composites after $\mathrm{pH}$ triggering. The degree of acidification in salmon slices by this procedure was found acceptable to 10 trained panellists that conducted a preliminary sensory panel (results were not given). The results of listerial counts during cold storage of smoked salmon slices coated with different films are presented in Table 3. The samples did not show any significant differences in $L$. innocua counts at $0^{\text {th }}$ day. However, the salmon slices coated with acidified LYS containing WP-OLE films showed significantly lower $(\mathrm{p}<0.05)$ L. innocua counts than all the other samples (uncoated, coated with WP-OLE, LYS containing WP-OLE (non-acidified) or WP-OLE (acidified) films) on the $1^{\text {st }}, 3^{\text {rd }}, 5^{\text {th }}$ and $7^{\text {th }}$ days of cold storage. It should also be reported that the L. innocua count of salmon slices packed with acidified LYS containing WP-OLE films was almost 0.6 decimals lower than those of uncoated salmon slices and WP-OLE coated salmon slices at the end of 1 week cold storage. The results in the first five days also clearly showed the lack of any considerable antimicrobial effect of non-acidified LYS containing WP-OLE films and acidified LYS lacking WP-OLE films. The results of the present study and the recent findings of Min et al., (2008) that successfully inhibited the growth of $L$. monocytogenes in cold stored salmon slices with LYS containing WP films clearly show the good potential of employing LYS containing edible WP films as an effective antilisterial hurdle.

\subsection{Mechanical properties of films}

The results showing film thickness, tensile strength at break, elongation at break and Young's modulus values of films are presented in Table 4. The incorporation of LYS and OLE into WP films did not cause a significant change in tensile strengths of films $(p>0.05)$, but a significant reduction $(p<0.05)$ occurred in tensile strength of films by incorporation of BW. This result was expected due to local disruptions of film matrix continuity with wax aggregates. A similar reduction of film tensile strength was also previously reported by Fabra et al. (2008) who incorporated BW into Nacaseinate films. The results also showed significant increases in film elongations by incorporation of LYS and OLE due to the plasticizing effects of indicated film components. The plasticizing effect of OLE was also reported by Arcan and Yemenicioğlu (2013) in zein films, but these authors did not determine any plasticizing effect of LYS in zein film system. In contrast, the incorporation of BW into WP films did not have any effect on film elongation. On the other hand, it should also be reported that the incorporation of LYS and OLE caused a significant reduction in Young's modulus values of WP films while addition of BW into WP film matrix did not cause any significant change in this parameter. The overall results of mechanical tests clearly showed the presence of some modifications in mechanical properties of WP film by incorporation of different ingredients, but the observed mechanical changes were not dramatic, and did not interfere with the applicability of the developed films.

\section{Conclusions}

The results of this work clearly showed the possibility of designing activate-at-home- type antimicrobial packaging materials, using LYS, OLE and WP films. The LYS release mechanism and antimicrobial activities of the designed films based simply on acidification of the film was successfully tested in laboratory model systems and on coated acidified smoked salmon slices stored at the standard cold storage temperature of $4{ }^{\circ} \mathrm{C}$. This study showed the possibility of employing antimicrobial edible films with $\mathrm{pH}$ controlled release properties to increase the safety of remained food left after opening of the original vacuum or modified atmosphere packaging at home. Further food applications are needed to optimize the inhibitory concentrations of LYS against L. monocytogenes at different conditions and determine the effects of antimicrobial packaging on different pathogenic bacteria.

\section{Acknowledgements}

We thank the Centres for Materials Research, and Biotechnology and Bioengineering at Izmir Institute of Technology (İzmir, Turkey) for providing their facilities to conduct some microscopic and antimicrobial studies of films used in this study, respectively.

\section{References}

Álvarez-Ordóñez, A., Leong, D., Hickey, B., Beaufort, A., \& Jordan, K. (2015). The challenge of challenge testing to monitor Listeria monocytogenes growth on ready-to-eat foods in Europe by following the European Commission (2014) Technical Guidance document. Food Research International, 75, 233-243.

Appendini, P., \& Hotchkiss, J. H. (1997). Immobilization of lysozyme on food contact polymers as potential antimicrobial films. Packaging Technology and Science, 10(5), 271-279.

Appendini, P., \& Hotchkiss, J. H. (2002). Review of antimicrobial food packaging. Innovative Food Science \& Emerging Technologies, 3(2), 113-126.

Arcan, I., \& Yemenicioğlu, A. (2013). Development of flexible zein-wax composite and zein-fatty acid blend films for controlled release of lysozyme. Food Research International, 51(1), 208-216.

ASTM. (2002). Standard test method for tensile properties of thin plastic sheetingD882-02. Philadelphia, PA: ASTM, Annual Book of American Standard Testing Methods.

Bower, C. K., Avena-Bustillos, R. J., Olsen, C. W., McHugh, T. H., \& Bechtel, P. J. (2006). Characterization of fish-skin gelatin gels and films containing the antimicrobial enzyme lysozyme. Journal of Food Science, 71(5), M141-M145.

Buchanan, R. L., \& Klawitter, L. A. (1990). Effects of temperature and oxygen on the growth of Listeria monocytogenes at pH 4.5. Journal of Food Science, 55(6), 1754-1756.

Cagri, A. Ustunol, Z. \& Ryser, E. T. (2001). Antimicrobial, mechanical, and moisture barrier properties of low $\mathrm{pH}$ whey protein-based edible films containing $\mathrm{p}$ aminobenzoic or sorbic acids. Journal of Food Science, 66(6), 865-871.

Cha, D. S., \& Chinnan, M. S. (2004). Biopolymer-based antimicrobial packaging: a review. Critical Reviews in Food Science and Nutrition, 44(4), 223-237.

Cha, D. S., Choi, J. H., Chinnan, M. S., \& Park, H. J. (2002). Antimicrobial films based on Na-alginate and $\kappa$-carrageenan. LWT-Food Science and Technology, 35(8), 
715-719.

Cooksey, K. (2005). Effectiveness of antimicrobial food packaging materials. Food Additives and Contaminants, 22(10), 980-987.

Dalgaard, P., \& Jørgensen, L. V. (1998). Predicted and observed growth of Listeria monocytogenes in seafood challenge tests and in naturally contaminated coldsmoked salmon. International Journal of Food Microbiology, 40(1), 105-115.

Dass, S. C., Abu-Ghannam, N., Antony-Babu, S., \& Cummins, E. J. (2010). Ecology and molecular typing of L. monocytogenes in a processing plant for cold-smoked salmon in the Republic of Ireland. Food Research International, 43(5), $1529-1536$.

Davies, A. R. (1997). Modified-atmosphere packaging of fish and fish products. In Fish processing technology (pp. 200-223). US: Springer.

Di Ciccio, P., Meloni, D., Festino, A. R., Conter, M., Zanardi, E., Ghidini, S., et al. (2012). Longitudinal study on the sources of Listeria monocytogenes contamination in cold-smoked salmon and its processing environment in Italy. International Journal of Food Microbiology, 158(1), 79-84.

Duan, J., Park, S. I., Daeschel, M. A., \& Zhao, Y. (2007). Antimicrobial chitosanlysozyme (CL) films and coatings for enhancing microbial safety of mozzarella cheese. Journal of Food Science, 72(9), M355-M362.

Duffes, F. (1999). Improving the control of Listeria monocytogenes in cold smoked salmon. Trends in Food Science \& Technology, 10(6), 211-216.

Etzel, M. R. (2004). Manufacture and use of dairy protein fractions. The Journal of Nutrition, 134(4), 996S-1002S.

Fabra, M. J., Talens, P., \& Chiralt, A. (2008). Tensile properties and water vapor permeability of sodium caseinate films containing oleic acid-beeswax mixtures. Journal of Food Engineering, 85(3), 393-400.

Gennadios, A., Hanna, M. A., \& Kurth, L. B. (1997). Application of edible coatings on meats, poultry and seafoods: a review. LWT-Food Science and Technology, 30(4), $337-350$.

Gram, L. (2001). Potential hazards in cold-smoked fish: Listeria monocytogenes. Journal of Food Science, 66(s7), S1072-S1081.

Han, J. H. (2000). Antimicrobial food packaging. Food Technology, 54(3), 56-65.

Han, J. H. (2003). Antimicrobial food packaging. In Novel food packaging techniques (pp. 50-70).

Joerger, R. D. (2007). Antimicrobial films for food applications: a quantitative analysis of their effectiveness. Packaging Technology and Science, 20(4), $231-273$.

Lu, H., Zhu, J., Li, J., \& Chen, J. (2015). Effectiveness of active packaging on control of Escherichia Coli 0157: H7 and total aerobic bacteria on iceberg lettuce. Journal of Food Science, 80(6), M1325-M1329.

Lynch, M. F., Tauxe, R. V., \& Hedberg, C. W. (2009). The growing burden of foodborne outbreaks due to contaminated fresh produce: risks and opportunities. Epidemiology and Infection, 137(03), 307-315.

Mastromatteo, M., Mastromatteo, M., Conte, A., \& Del Nobile, M. A. (2010). Advances in controlled release devices for food packaging applications. Trends in Food Science \& Technology, 21(12), 591-598.

McHugh, T. H., \& Krochta, J. M. (1994). Sorbitol-vs glycerol-plasticized whey protein edible films: integrated oxygen permeability and tensile property evaluation. Journal of Agricultural and Food Chemistry, 42(4), 841-845.

Mecitoğlu, Ç., Yemenicioğlu, A., Arslanoğlu, A., Elmacı, Z. S., Korel, F., \& Çetin, A. E.
(2006). Incorporation of partially purified hen egg white lysozyme into zein films for antimicrobial food packaging. Food Research International, 39(1), $12-21$.

Mendes de Souza, P., Fernández, A., López-Carballo, G., Gavara, R., \& HernándezMuñoz, P. (2010). Modified sodium caseinate films as releasing carriers of lysozyme. Food Hydrocolloids, 24(4), 300-306.

Min, S., Rumsey, T. R., \& Krochta, J. M. (2008). Diffusion of the antimicrobial lysozyme from a whey protein coating on smoked salmon. Journal of Food Engineering, 84(1), 39-47.

Nilsson, L., Huss, H. H., \& Gram, L. (1997). Inhibition of Listeria monocytogenes on cold-smoked salmon by nisin and carbon dioxide atmosphere. Internationa Journal of Food Microbiology, 38(2), 217-227.

Ouattara, B., Simard, R. E., Piette, G., Bégin, A., \& Holley, R. A. (2000). Inhibition of surface spoilage bacteria in processed meats by application of antimicrobial films prepared with chitosan. International Journal of Food Microbiology, 62(1) 139-148.

Park, S. I., Daeschel, M. A., \& Zhao, Y. (2004). Functional properties of antimicrobial lysozyme-chitosan composite films. Journal of Food Science, 69(8), M215-M221.

Pérez-Pérez, C., Regalado-González, C., Rodríguez-Rodríguez, C. A., BarbosaRodríguez, J. R. \& Villaseñor-Ortega, F. (2006). Incorporation of antimicrobial agents in food packaging films and coatings. Advances in Agricultural and Food Biotechnology, 193-216.

Quintavalla, S., \& Vicini, L. (2002). Antimicrobial food packaging in meat industry. Meat Science, 62(3), 373-380.

Shah, N. P. (2000). Effects of milk-derived bioactives: an overview. British Journal of Nutrition, 84(S1), 3-10.

Suppakul, P., Miltz, J., Sonneveld, K., \& Bigger, S. W. (2003). Active packaging technologies with an emphasis on antimicrobial packaging and its applications. Journal of Food Science, 68(2), 408-420.

Tsigarida, E., Skandamis, P., \& Nychas, G. J. (2000). Behaviour of Listeria monocytogenes and autochthonous flora on meat stored under aerobic, vacuum and modified atmosphere packaging conditions with or without the presence of oregano essential oil at $5^{\circ} \mathrm{C}$. Journal of Applied Microbiology, 89(6), 901-909.

Unalan, I. U., Arcan, I., Korel, F. \& Yemenicioğlu, A. (2013). Application of active zeinbased films with controlled release properties to control Listeria monocytogenes growth and lipid oxidation in fresh Kashar cheese. Innovative Food Science \& Emerging Technologies, 20, 208-214.

Unalan, I. U., Korel, F., \& Yemenicioglu, A. (2011). Active packaging of ground bee patties by edible zein films incorporated with partially purified lysozyme and Na2EDTA. International Journal of Food Science \& Technology, 46(6), 1289-1295.

Unalan, I. U., Ucar, K. D. A Arcan, L, Korel, F. \& Yemenicioglu, A. (2011). Antimicrobial potential of polylysine in edible films. Food Science and Technology Research, 17(4), 375-380.

Vazquez-Boland, J. A., Kuhn, M., Berche, P., Chakraborty, T., Dominguez-Bernal, G. Goebel, W., et al. (2001). Listeria pathogenesis and molecular virulence determinants. Clinical Microbiology Reviews, 14, 584-640.

Vermeulen, A., Devlieghere, F., De Loy-Hendrickx, A., \& Uyttendaele, M. (2011). Critical evaluation of the EU-technical guidance on shelf-life studies for L monocytogenes on RTE-foods: a case study for smoked salmon. International Journal of Food Microbiology, 145(1), 176-185. 